Journal of American Studies, o (20 I 7), O, I-20

(C) Cambridge University Press and British Association for American Studies 2017

\title{
Colliding Worlds: The Disintegration of America in the Cinema of the Coen Brothers
}

\author{
THORSTEN CARSTENSEN
}

In the cinema of Joel and Ethan Coen, contemporary America is depicted as an incoherent space in which traditional beliefs constantly collide with the new world order. Shaped by the erosion of commonly accepted values and the ubiquitous presence of the media and advertisements, this hybrid America is a world of commerce, consumption, and economic plight. While its cities are plagued by segregation, outbursts of casual violence undermine the myth of an unspoiled life in the countryside. Illustrating postmodern culture's preference for the periphery versus the center, the movies of the Coen brothers find a glimmer of morality remaining on the margin of society. Unimposing and compassionate characters such as the pregnant small-town detective in Fargo or the naive yet brilliant protagonist of The Hudsucker Proxy personify an idealistic, innocent America that is about to be displaced by selfish greed. Focusing on Fargo, The Big Lebowski, and The Man Who Wasn't There, my essay argues that the Coens' visual playfulness, and their tendency to mine various cinematic genres, serve to emphasize their scathing critique of the American victory narrative.

In the cinema of Joel and Ethan Coen, contemporary America is depicted as an incoherent space in which traditional beliefs constantly collide with the new world order. Shaped by the erosion of commonly accepted values and the ubiquitous presence of the media and advertisements, this hybrid America is a world of commerce, consumption, and economic plight. While its cities are plagued by segregation, outbursts of casual violence undermine the myth of an unspoiled life in the countryside. Illustrating postmodern culture's preference for the periphery versus the center, the movies of the Coen brothers find a glimmer of morality remaining on the margin of society. Unimposing and compassionate characters such as the pregnant small-town detective in Fargo or the naive yet brilliant protagonist of The Hudsucker Proxy seemingly evoke the memory of an idealistic, innocent America. However, whereas the Hollywood blockbusters of the Reagan era often glorified the myth of the western frontier and sought to reinforce a new 
national narrative of confidence after the trauma of Vietnam, the Coens deconstruct the American success story by depicting a country that clearly is - and always has been - on the brink of moral corruption.

In what follows, I will argue that the cinema of the Coen brothers presents the viewer with a critical assessment of America's late capitalist society. It does so by posing questions of identity, authenticity, history, and ethics in a postmodern context. The Coens' rendering of contemporary America is reminiscent of Jean-François Lyotard's view of postmodern society as a fragmented world composed of disparate communities and language games, each with its own set of values, ideologies, and behavioral codes. Designed to raise ontological questions, films such as Barton Fink (1991), The Hudsucker Proxy (1994), Fargo (1996), The Big Lebowski (1998), and The Man Who Wasn't There (200I) stage collisions of conflicting worlds. Both a plot technique and an ideological device, this juxtaposition of incommensurable realities is particularly obvious in The Ladykillers (2004), which confronts the old-fashioned virtues of the American South - charity, gospels, Sunday churchgoing with an eclectic world of junk and pop culture: "hippity-hop music," football games, men's magazines, and, most notably, the rampant consumerism embodied by casinos, strip malls, and television commercials. In The Ladykillers, the apparent chasm between past and present lifestyles is underscored in a scene where the old lady Marva Munson travels from her wellmaintained house in the suburbs to the run-down buildings and neglected urban spaces on the other end of town.

On the visual level, the Coen brothers invest a familiar world with strangeness, thus painting a flashy portrait of post-1945 America that is simultaneously vividly realistic and grotesquely imaginative. Even though this selfcontained cosmos overlaps with the empirical world, it is in fact a blatantly creative projection, drawing on a collective perception of reality that is always predetermined by mediated images. Taken to its extreme, as it was in their latest film, Hail, Caesar! (2016), the Coens' obsession with borrowing styles, settings, plots, and characters - their "self-destructive whirl of unhinged pop scholarship," to quote New Yorker critic David Denby - results in the creation of a hyperreal cinematic theme park. Resisting the linear approach to storytelling typical of traditional Hollywood, their aesthetic of excess, exemplified by a fascination with ornamentation and what James Naremore terms a "fetishistic" gusto for small details that do little to propel the plot, ${ }^{2}$ calls

I David Denby, "Killing Joke: The Coen Brothers' Twists and Turns," New Yorker, 25 Feb. 2008.

2 James Naremore, More than Night: Film Noir in Its Contexts, updated and expanded edn (Berkeley: University of California Press, 2008), 215 . Reviewers of their films have often 
attention to the filmmaking process itself and opens the film to the audience's own imagination and interpretation.

In classical Hollywood cinema, the goal-driven modernist plot is usually propelled by the desire to resolve any clash of order and disorder. By contrast, the Coens' exploration of America's spatial, linguistic, and moral disintegration is rooted in a sensibility that suspends the laws of cause and effect and sees the world as "both undetermined and undetermining." " Confronted with the manifest "irregularity" of people's behaviors and everyday events to quote The Ladykillers' eloquent impostor, Professor G. H. Dorr - the Coens' protagonists seem to drift through a parallel universe of violence characteristic of postmodern cinema. ${ }^{4}$ Their often comical failure to convey their feelings and thoughts, as well as their involvement in schemes that are doomed to implode, point to what R. Barton Palmer calls the Coens' interest in "the twin impossibilities of human experience: coming to any meaningful understanding of others and mastering a brute reality ruled by the principle of seemingly diabolical mischance."s Lacking a reliable framework for their actions, and prone to obsessive decision making, the Coens' characters embark on erratic journeys shaped by random encounters. Eventually they surrender to forces beyond their control, realizing that, as the Stranger in The Big Lebowski puts it, "sometimes you eat the bear and sometimes, well, the bear eats you."

\section{NOSTALGIA AND THE CRITIQUE OF THE AMERICAN DREAM}

The movies of Joel and Ethan Coen close the gap between high and low art forms in the ways that they entertain and signify. The postmodern allure of their cinema emanates from their incessant referencing and recycling of preexisting texts. In his essay "Reflections on The Name of the Rose," Umberto Eco argues, "The postmodern reply to the modern consists of recognizing that the past, since it cannot really be destroyed, because its destruction leads to silence, must be revisited: but with irony, not innocently." ${ }^{6}$ In the Coens' cinema,

noted the Coens' penchant for ornate elements. See, e.g., Todd McCarthy, "The Hudsucker Proxy," Variety, 3 I Jan. I994.

${ }^{3}$ Zygmunt Bauman, Intimations of Postmodernity (London and New York: Routledge, I 992), I 90 .

${ }^{4}$ For a short analysis of the "bleak and threatening world" that the characters in the Coens' Blood Simple (1984) encounter see Carl Boggs and Tom Pollard, A World in Chaos: Social Crisis and the Rise of Postmodern Cinema (New York: Rowman and Littlefield, 2003), 87-88.

5 R. Barton Palmer, Joel and Ethan Coen (Urbana and Chicago: University of Illinois Press, 2004), 53.

${ }^{6}$ Umberto Eco, Postscript to The Name of the Rose (London and New York: Harcourt, I983), 67. 
history returns as resourceful eclecticism - as an "antiquarian pastiche" that draws on, defamiliarizes, and transforms a multitude of sources in order to produce a vague sense of the past, remaking "movies that were never made in the first place."' The lyrics of the Four Tops" "It's the Same Old Song," featured in their earliest film, Blood Simple (1984), aptly summarize the directors' attitude toward cinematic history: "It's the same old song, but with a different meaning since you've been gone."

The Coen brothers' intricate play of intertextual codes and meanings is particularly striking in Miller's Crossing, which is often charged with being little more than a self-indulgent exercise in deconstructing the gangster genre. A film on which the real world impinges "only by accident," 8 as Canby observes, Miller's Crossing exemplifies postmodern fascination with the hyperreal. The aesthetics of Miller's Crossing are utterly self-referential in character, parodying the plethora of old-time gangster melodramas by evoking both the settings and the decor of films such as The Glass Key and The Maltese Falcon. ${ }^{9}$ Set during Prohibition in an unnamed city run by Irish and Italian gangs, Miller's Crossing presents the audience with a world inhabited by pragmatic mobsters who are in the habit of double-crossing each other - which, it turns out, is bad for business. Johnny Caspar, one of the town's bosses, is losing money on fixed boxing fights because his intermediary is selling insider information. As a consequence of this lack of "friendship, character, ethics," nothing and nobody can be trusted. ${ }^{\circ}{ }^{\circ}$ Caspar complains:

It's a wrong situation. It's gettin so a businessman can't expect no return from a fixed fight. Now if you can't trust a fix, what can you trust? For a good return you gotta go bettin' on chance, and then you're back with anarchy. Right back inna jungle. On account of the breakdown of ethics. That's why ethics is important.

The profound sense of uncertainty that Caspar laments is accentuated by the film's recourse to a film noir style of confusion and destabilization. The murky lighting is employed for obscuration, creating a hostile atmosphere in which the boundaries between truth and fiction, good and evil, and friend and foe are completely blurred. Shadowed faces suggest the characters' enigmatic identities. As the protagonist Tom Reagan puts it, "Nobody knows anybody that well." He is told "to make sure you're with the good guys." But as he immerses

7 A. O. Scott, "A Gang of Impostors vs. One True Lady," New York Times, 26 March 2004.

${ }^{8}$ Vincent Canby, "In 'Miller's Crossing,' Silly Gangsters and a Tough Moll," New York Times, 2 I Sept. I 990.

Cf. Naremore, 2 I 4.

${ }^{10}$ For a discussion of the film's concern with ethics and codes of conduct see Bradley L. Herling, "Ethics, Heart, and Violence in Miller's Crossing," in Mark T. Conard, ed., The Philosophy of the Coen Brothers, updated edn (Lexington: University Press of Kentucky, 20I2), I 25-46. 
himself in the postmodern underworld, he gradually realizes that "things are not as clear-cut as you think" and that "up is down, black is white."

The Coens' attack on authenticity is also evident in both the setting and the mise en scene of The Hudsucker Proxy. Evoking the hyperreal image of a time that never really existed, the film dips into a collective memory of standardized representations of the past. The audience is presented with a nostalgic, mediagenerated image of New York City that cannot be traced back to an original idea. The film romanticizes Mies van der Rohe's "hollow glass shells," as Lewis Mumford called them, and reactivates these "elegant monuments of nothingness" for the sake of postmodern style. ${ }^{\text {I }}$ Nothing substantial lies behind the artificial facade of these hackneyed images. The city's skyline gives the impression of an exuberant backdrop set up only to bedazzle and hypnotize the viewer. A carefully orchestrated pastiche of collective images from Hollywood's glamorous past, this New York is pure surface, invoking nostalgia for earlier films while also parodying their conventions. ${ }^{12}$ As Palmer sums up, "Every element of the film is a quotation." 13 Thus interpreting The Hudsucker Proxy becomes an intellectual interaction between the knowledge of the filmmaker and the audience's awareness of cinematic history.

The movie opens with a long tracking shot of the night sky. As the shot continues, the camera pans across the snow-covered tops of skyscrapers, revealing what Baudrillard has called the "baroque verticality" of New York City. ${ }^{14}$ Although the story is set in 1958 , the mise en scene - with its focus on the architectural modernism of the city, the formal order of the streets, and the art deco character of the offices - bears strong stylistic resemblances to the movies of Preston Sturges and Frank Capra. Even Fritz Lang's Metropolis is recycled in the double-world structure of Hudsucker Industries; the chaotic mailroom in the basement is contrasted with orderly offices on the fortyfourth floor. The Coens themselves have described their style as a mixture of "the architecture of Albert Speer [and] the design and scale of Terry Gilliam." Is

According to David Bordwell, classical Hollywood cinema strives to convince the audience that the raw material of the story, rather than being

${ }^{11}$ Lewis Mumford, The Highway and the City (New York: Harcourt, Brace \& World, I963), I 67.

12 This cinematic mix of nostalgia and parody has often been identified as quintessentially postmodern. See Norman K. Denzin, Images of Postmodern Society: Social Theory and Contemporary Cinema (London: Sage, I991), Io.

I3 Palmer, I 40. For a detailed analysis of this escalating mode of allusion and referencing see also Paul Coughlin, "The Past Is Now: History and The Hudsucker Proxy," in Conard, 195-209.

${ }^{14}$ Jean Baudrillard, America, trans. Chris Turner (London and New York: Verso, I 988), 22.

is John Naughton, "Double Vision," Premiere, Sept. 1994. 
a construction, "preexisted its narrational representation." ${ }_{16}$ By narrating the story invisibly, movies in the I940s and I 950 s typically sought to create an illusion of authenticity. The Coens' metafictional cinema challenges this "concealment of production," as the narrator's remarks at the onset of The Hudsucker Proxy illustrate. The movie starts out by turning back time in a long flashback, thus disorienting the viewer and undermining the realist pretensions of classical Hollywood. While the narrator introduces us to a man high up on the Hudsucker skyscraper, ready to throw himself from the forty-fourth floor, we are also informed that what we are about to watch is in fact the story's ending: "How'd he get so high? An' why is he feelin' so low? Is he really gonna do it - is Norville really gonna jelly up the sidewalk?" Before any of these questions can be answered, the camera loses Norville from the frame and slowly moves into the enormous clock. The narrator then declares that the future is "something you can never tell about," while the past is "another story." It is this story about the past that the movie is interested in, a story composed of the imagery of the American Dream and its transformation into Hollywood myth. The audience will not learn whether Norville is really going to jump until the very end of the movie when the narrative circle comes to a close. In the final shot, as Norville throws himself off the company building, time freezes and the arms of the giant clock cease their movement. With his head down and feet up in the air, Norville is suspended in midair, and so is the narrative.

In the classical Hollywood narrative, style is subordinated to action; the image is there to propel the plot, and to elucidate characters' motivations and feelings. In the cinema of the Coen brothers, however, the plot is often secondary to stylistic playfulness. In moments of self-absorption, they reduce the function of the cinematic apparatus to conveying visual pleasure. This happens, for instance, in the hula-hoop episode of The Hudsucker Proxy. Suspending the main plot line, this episode is a prime example of a postmodern aesthetics that tends to focus on independent moments, carved out of any larger context. The shape of the hula hoop, first presented by Norville Barnes as a plain circle on a sheet of paper ("You know ... for kids"), is mirrored by the film's mise en scene and the circular structure of its narrative. It is further suggested by the giant illuminated clock that dominates the facade of the Hudsucker building, a quotation from John Farrow's I 948 film noir The Big Clock. Throughout the movie, such circular forms are contrasted with the vertical lines of the skyscrapers, a strategy that produces stylistic tension.

${ }^{16}$ David Bordwell, "Classical Hollywood Cinema: Narrational Principles and Procedures," in Philip Rosen, ed., Narrative, Apparatus, Ideology: A Film Theory Reader (New York: Columbia University Press, I986), 17-34, 24. 
Marxist cultural critics have emphasized the neoconservative nature of postmodern nostalgia films, of which Miller's Crossing and The Hudsucker Proxy are prime examples. For the Coen brothers, however, the ironic reworking of the past serves a fundamentally critical purpose. In their movies the parody of older styles and narratives is as much a comic meditation on genre boundaries and conventions as it is a springboard for assessing the moral state of the nation. This is particularly true of The Hudsucker Proxy, where the nostalgic mode offers an opportunity to identify problematic continuities and discontinuities between the frequently romanticized era of postwar economic boom and the America of late capitalism. The historical context serves as backdrop for a critical investigation of the generic American Dream of self-realization, according to which everybody can rise from dishwasher to millionaire - or from a job in the mailroom to the forty-fourth floor of Hudsucker Industries, the biggest corporation in a world of big corporations. The America of The Hudsucker Proxy is a country that has always been based on capitalist principles, as the narrator admits, "Time is money, and money drives that ol' global economy and keeps big Daddy Earth a-spinnin' on roun'."

Towards the end of the movie, Norville reads Waring Hudsucker's remorseful farewell letter, in which the company's former president bemoans his own corruption of character and ideals: "I see that I allowed time and age to corrupt my dreams. Instead of fiercely guarding what was timeless inside of myself, I let the hubbub of earthly commerce erode my character, and dissolve my better self." Waring Hudsucker's insight into his personal moral failures constitutes a key moment in the cinema of the Coen brothers, hinting at their liberal critique of contemporary American society. It therefore comes as no surprise that Norville Barnes, originally hired because of his perceived incompetence, succeeds Waring as chairman of the board. Instead of destroying the company's reputation and devaluing the stock so that the other board members can buy it at a low price - a plan for which Norville was hired in the first place - the recent business graduate manages the commercial operations "with wisdom and compassion." Thus naivety and imagination triumph over big business; the morally intact individual rises above the world of corruption. As Waring Hudsucker writes in his farewell letter, "The future belongs to the young, who may more energetically wage the battle against corruption ... For while we must strive for success, we must not worship it."

\section{THE FORGOTTEN AMERICA}

The pluralism of realities is a recurring theme in postmodern culture. According to Brian McHale, the collision of different worlds is the defining 
characteristic of postmodernist fiction. Drawing on Foucault's concept of a heterotopia - an impossible space in which a large number of possible worlds coexist - McHale argues that postmodern characters are confronted with ontological questions: "Which world is this? What is to be done in it? Which of my selves is to do it?" ${ }^{77}$ In David Lynch's film Blue Velvet (1986), for instance, the innocent suburban antihero constantly moves back and forth between a mundane world of green lawns and family dinners, and an alternate realm of passion, aggression, and utter moral disintegration.

The Coens' cinema frequently draws on the idea of a multiplicity of worlds. Perhaps the most ostentatious variation of this structural device in their oeuvre can be found in one of their minor comedies, The Ladykillers. The film's protagonist, G. H. Dorr, embodies the collapse of any neat binary opposition. Supposedly a professor of classics, this well-mannered southern gentleman is attracted to the forces of a dark, irrational underworld, as illustrated by his love of the Romantic poet Edgar Allan Poe. As Dorr assembles his team of small-time crooks in the basement of Marva Munson's suburban home, where they plot to rob the local riverboat casino, the Bandit Queen, the Coens create obvious spatial parameters to reflect their ontological concerns: the cradle of the violence- and greed-ridden underworld is located quite literally below the mundane upper world. In a skillful sequence that juxtaposes shots of the robbery with images of the old lady's visit to her local Baptist church, the disintegration of American society becomes most apparent. While Mrs. Munson sings along with the gospels, her tenant is busy carrying out the perfect crime. By cross-cutting between these two worlds, the Coens visualize their critique of the ongoing corruption of American values, as well as their sentimental yearning for a return to innocence. This seemingly straightforward juxtaposition is complicated by the fact that Mrs. Munson is unaware of the contradictions shaping her unwavering commitment to religion, for she sends a monthly check for five dollars to Bob Jones University in Greenville, South Carolina, "the finest [Bible study] school in the country" - a school that did not admit black students until the 1970s. ${ }^{18}$

The merging of two incompatible layers of American reality also informs Fargo, a dark morality tale in which the setting - the barren landscape of rural Minnesota - reflects the moral bankruptcy of middle-class life. ${ }^{19}$ Fargo propounds questions about the coexistence of disparate worlds by contrasting

${ }_{17}$ Brian McHale, Postmodernist Fiction (New York and London: Methuen, 1987), io.

${ }^{18}$ On the role of religion in The Ladykillers see Allen H. Redmon, Constructing the Coens: From Blood Simple to Inside Llewyn Davis (Lanham, MD: Rowman \& Littlefield, 2015), 28-3i.

19 Christopher Sharrett, "Fargo, or the Blank Frontier," in William G. Luhr, ed., The Coen Brothers' Fargo (Cambridge: Cambridge University Press, 2004), 55-76, 62. 
the homey, small-town environment of Brainerd - "Home of Paul Bunyan and Babe the Ox," as a roadside sign proudly announces - with its underbelly of crime and violence. Throughout the movie, the postmodern obliteration of boundaries is emphasized by shots of constantly falling snow. Like the rain in The Big Sleep, the Minnesota snow is both an atmospheric device and a selfconscious reminder of the labyrinthine plot structure in film noir. The fusion of worlds is already implicit in the movie's surreal opening shots in which the overcast skies, drifting snow, and white country fields seem to melt into one another. The framing is reminiscent of a surrealist painting, disorienting the viewer with its invisible horizon and diffuse lighting. A car emerging out of the snow seems to be lost in time, coming from and going to nowhere. Contrary to classical Hollywood style, this opening sequence does not establish a clear sense of space but rather foreshadows a disturbing world of ubiquitous confusion. We are confronted here with a de-romanticized blank frontier, as Sharrett calls it - an empty and endless wasteland of snow. ${ }^{20}$ This miserable, frozen wilderness forms an inverse western frontier: not the manifestation of great hopes, but the metaphorical consequence of an unfulfilled promise.

Postwar film noir held a dark mirror up to America's moral corruption. Fargo, a postmodern, rural version of film noir, portrays a nation corroded by greed and what Fredric Jameson has called "the logic of late Capitalism." As Sharrett argues, the film can be viewed as "the summary statement about the U.S. at the end of the American Century, as surely as John Ford's works celebrated America's emergence as a major world power." ${ }^{21}$ In Fargo, the triumph of post-Reagan consumerism seems to have resulted in a spiritual and emotional vacuum. ${ }^{22}$ The inconspicuous car dealer Jerry Lundegaard embodies the contamination of Middle America. Managing a showroom in the sprawling suburban landscape of great distances, this inadequate allAmerican, middle-class businessman belongs to a world shaped by the "commercial persuasion of roadside eclecticism." ${ }_{23}$ Jerry has been corrupted by the allure of late capitalism, and greed has turned him into a small-time crook. Faced with large debts he cannot pay, he thinks up a plan that is as bizarre as it is morally depraved. He hires two criminals to kidnap his wife, assuming that his wealthy father-in-law will provide the ransom money. For Jerry and the two thugs, however, plotting a kidnapping proves to be far beyond their

${ }^{20}$ Sharrett, 60-62.

${ }^{21}$ Christopher Sharrett, "Year of the Independents," USA Today, March 1997.

${ }^{22}$ See Sharrett, "Blank Frontier," 57.

${ }^{23}$ Robert Venturi, Denise Scott Brown, and Steven Izenour, Learning from Las Vegas: The Forgotten Symbolism of Architectural Form (Cambridge, MA and London: MIT Press, I 977), 8. 
intellectual and practical means. Due to the incompetence of almost everyone involved, the kidnapping plot spins completely out of control. Naturally, Jerry and his accomplices are oblivious to the main lesson taught by the Coens' cinema (and voiced by the private detective in Blood Simple): "Now I don't care if you're the Pope in Rome, President of the United States, or man of the year, something can always go wrong."

Conversations in this context also result in ludicrous misunderstandings since each character is trapped in his or her own individual language game. Instead of acting according to a well-designed plan, they seem to reenact scenes from film and television. Unable to deal with complex situations verbally, the kidnappers resort to violence. Hence, when a state trooper pulls over the two kidnappers because they forgot to replace the dealer plates on the car with proper tags, their attempt to communicate - in a language that imitates television drama-further arouses the officer's suspicion. They resolve the situation by shooting both the state trooper and two witnesses. With the camera's eye tracking the blood-colored snow, this scene strikingly visualizes the fusion of purported small-town innocence and capital crime. Even in rural Minnesota, meaningful communication has been replaced by random eruptions of violence.

On the fringe of this environment shaped by a "psychic atmosphere of latent dread covered over by a forced normalcy," ${ }^{24}$ there is Marge Gunderson, the pregnant police officer who represents the last outpost of compassionate modernism in a postmodern world devoid of moral concerns. Thomas Doherty gets to the heart of her character when he states, "As the detective ratiocinator, Marge pretty much defies every Raymond Chandler cliché - no cynicism, no witticisms, no eroticism." 25 A vivid antithesis of the traditional detective, Marge is one of those Coen characters who, as Richard Schickel observes, "appear at first glance to be simple souls but are, in fact, the salt of our earth." According to Schickel, these marginalized figures "have so internalized their morality that it comes out as just plain common sense, funnily understated." ${ }^{26}$ Elevated to central importance in postmodern film and fiction, these eccentric characters on the periphery of society overthrow existing hierarchical structures and defeat the evils of late capitalism. This becomes overtly clear when Marge lectures the surviving criminal: "There's more to life than money, you know."

Marge is a folk hero, a modern-day Paul Bunyan figure situated on the rural margin of contemporary America. Unlike Jeffrey Beaumont in Blue Velvet or

\footnotetext{
24 Sharrett, "Blank Frontier," 58.

25 Thomas Doherty, "Fargo," Cineaste, 22, 2 (1996), 47-55, 47.

26 Richard Schickel, "Dandy Dodgy Lodgers," Time, 29 March 2004, 60.
} 
Ed Crane in The Man Who Wasn't There, she withstands the alluring forces of the underworld. Throughout the investigation, Marge displays a moral integrity that appears old-fashioned in comparison to a zeitgeist that embraces individualism and political irresponsibility. Even while exploring society's cruel underbelly, she finds time to soothe her husband Norm, whose repeated failures as an amateur artist serve as a comic antidote to her career in the local police force. Furthermore, Marge's pregnancy suggests a domestic territory unsoiled by the influence of the late capitalist system. She belongs to the old pastoral world, a forgotten America associated with positive qualities such as modesty, honesty, righteousness, and the ability to love. Consequently, after a series of absurdly casual acts of violence, the final scene of the film, in which Marge and Norm are curled up in bed, seems to imply that Middle America's redemption is still possible. But while they proclaim their love for one another and slowly drift off to sleep, the television playing in the background suggests that the sphere of innocence established by the Coens is always already permeated by capitalism's dreams and demands. To paraphrase Umberto Eco, innocent treatment has given way to ironic treatment.

\section{“LET'S GO BOWLING”: LANGUAGE GAMES AND COMPANIONSHIP}

As I have shown in my discussion of visual style in The Hudsucker Proxy, the cinema of the Coen brothers eliminates the boundaries between past and present. In The Big Lebowski, time is clearly out of joint. The convoluted narrative assembles stereotypical figures, locations, and attitudes from different time periods, thus transforming Los Angeles into a space of postmodern imagination. The city is introduced as a mix of different historical periods that merge into a timeless present. As Mottram sums up, "Part Western, part Busby Berkley musical, part Philip Marlowe homage, the film is as diverse as the inhabitants of its central location, Los Angeles." ${ }_{27}$ While in traditional Hollywood the concept of genre determines a movie's theme, character types, and narrative structure, The Big Lebowski ignores the conventions and rules of one particular genre, instead assembling elements from detective stories, romances, and buddy narratives alike. The characters include an oldtime cowboy who reminds the viewer of America's past as a frontier nation, the former members of a 1970 S German electronic rock band, a Vietnam veteran who is still trapped in his traumatic experience as a soldier in the Southeast Asian jungle, and a wealthy entrepreneur who has adopted the language of the Reagan era. Finally, there is the Dude, who spent his college career

\footnotetext{
${ }^{27}$ James Mottram, The Coen Brothers: The Life of the Mind (Dulles, VA: Brassey's, 2000), I 32.
} 


\section{2 Thorsten Carstensen}

"occupying various administration buildings, smoking Thai-stick, breaking into the ROTC, and bowling." The bowling alley, with its peak of popularity back in the 1950s, completes a landscape in which, as Harvey puts it, "spaces of very different worlds seem to collapse upon each other." ${ }^{28}$ The superimposition of disparate realities is already established in the movie's opening scene, in which the camera follows the Dude as he strolls down the aisles of a supermarket. While a small television placed next to the cash register shows George Bush standing on the White House lawn delivering his speech on Iraq's invasion of Kuwait ("This aggression will not stand"), the Dude writes a check to the supermarket for sixty-nine cents, the entirety of his purchase. With their meticulous mise en scène, the Coens suggest that in America, the realms of aesthetics, culture, consumerism, and politics perpetually interlock.

With its associative combination of urban decay, moral depravity, and the illusion of quick success, Los Angeles has long been a preferred topos in Hollywood cinema and television drama. As Andrew Spicer writes in the context of film noir, the Californian metropolis has often been represented as an "amorphous city" that produces the impression of a futuristic "centrifugal sprawl with no centre." ${ }^{29}$ Unlike the stereotypical New York of The Hudsucker Proxy, which is composed of modernist clichés that seek to produce an ironic surface of harmony and unity, the Los Angeles of The Big Lebowski emerges as an inherently postmodern space. The city may be socially and ethnically pluralistic, but it remains a strictly segmented environment. Once the various zones clash, an eruption of anarchy is inevitable. It is the job of local authorities to prevent chaos by enforcing the city's segregation. ${ }^{3 \circ}$ As one police officer tells the Dude, "Keep your ugly fucking gold-bricking ass out of my beach community!" In this space of unrestrained individualism, the universally accepted notion of self-realization, whether through artistic or financial means, is challenged by an almost mythical code of honor and a quaint sense of community, upheld by the Dude and his bowling buddies.

The Big Lebowski opens with the camera floating up a steep, scrubby slope, following a gently moving tumbleweed. This recurrent image of the tumbleweed floating through the deserted avenues of Los Angeles, echoing the city's

${ }^{28}$ David Harvey, The Condition of Postmodernity: An Enquiry into the Origins of Cultural Change (Oxford: Blackwell, I989), $30 \mathrm{I}$.

29 Andrew Spicer, Film Noir (New York: Longman, 2002), 74.

30 According to Marshall Berman, the spatial design of the postmodern city is supposed to prevent collisions and confrontations between incommensurable fractions of society. Marshall Berman, All That Is Solid Melts into Air: The Experience of Modernity (London: Verso, 1983), I64. 
representation in both film noir and the novels of Raymond Chandler, sets the tone for a story about dislocated characters struggling to make sense of a meaningless world. The first two lines of the bluegrass ballad "Tumbling Tumbleweeds" capture the isolation and metaphysical homelessness experienced by the characters: "I'm a roaming cowboy riding all day long / Tumbleweeds around me sing their lonely song." As the tumbleweed is blown along the plains, the Dude is blown across the meandering city by chance, without making much effort to determine the outcome of his actions. His lack of direction, as well as his utter satisfaction with this random existence, are perfectly summed up in the "Tumbling Tumbleweeds" ballad:

Cares of the past are behind

Nowhere to go but I'll find

Just where the trail will wind

Drifting along with the tumbling tumbleweeds.

Cheerfully ignoring society's conventions, the Dude is nothing but "a man," as the voice-over repeatedly introduces him, "quite possibly the laziest in Los Angeles County." With his indifference and his lack of ambition, the Dude embodies the antihero in postmodern cinema; he is "the man for his time 'n' place," as the voice-over exclaims; "he fits right in there." The Dude is one of those "dazed and distracted characters" who wander through postmodern spaces "without a clear sense of location," as David Harvey puts it. ${ }^{3}$ It is a case of confused identity that sends the Dude on his picaresque journey across the sprawling suburban landscape of Los Angeles. When the scruffy ex-hippie, whose "real-life" surname is Lebowski, gets mistaken for a millionaire named Jeffrey Lebowski, who happens to reside in an obscenely luxurious villa in Pasadena, his relaxed life on the margin of American society takes a violent and unexpected turn. Returning home one night, the Dude is overwhelmed by strangers who have broken into his apartment to demand "the money" and end up soiling his rug. This random encounter serves as the starting point for a detective story that lacks a real detective. The Dude "is a shambling version of Philip Marlowe," ${ }_{32}$ stumbling through a convoluted plot that centers on a kidnapping mystery. He reluctantly seeks compensation for his ruined rug, repeating George Bush's famous claim that "this aggression will not stand." As he plunges deeper into unknown territory, his utter disorientation is mirrored by the deliberately incoherent structure of the narrative. Portrayed throughout the film as a morally dilapidated city steeped in fraudulence, Los Angeles serves as an appropriate setting for a labyrinthine plot of "a lot of ins and outs." 
Never intending to be caught up in the mystery, all the Dude "ever wanted was his rug back." In other words, the film uses the rug as a narrative device to create motivation for the character and thus push the plot along. When the Dude enters the mansion of the real Jeffrey Lebowski to ask him to replace his soiled rug, in a scene reminiscent of the opening sequence of Coppola's The Godfather, he involuntarily becomes part of an intricate criminal plot that is bound to run out of control. More exactly, with an ironic nod to The Godfather Part II, the rug itself signals the protagonist's descent into the underworld. In one of the flashbacks in Coppola's movie, the young Vito Corleone is drawn into the mafia world of his parents when he accepts a stolen rug as a reward for hiding another gangster's weapons. In both The 
men, at Khe San and Lan Doc and Hill 364. These young men gave their lives. And Donny too. Donny who ... who loved bowling.

Trapped in his Vietnam trauma, Walter automatically relates Donny's death to the fate of thousands of young American soldiers during the war. In this world shaped by a profound sense of uncertainty, Walter's obsession with the past - comically reflected by the fact that he takes care of his former wife's dog while she is on holiday with her new partner - serves to stabilize his fragile identity. This also holds true for his adamant observation of the bowling rules, culminating in his argument with Smokey, whom he accuses of having slipped over the line while throwing the ball: "This is not Nam," Walter insists, "This is bowling. There are rules." Taking out a gun, he reveals his fundamental frustration with the world's arbitrariness: "Has the whole world gone crazy? Am I the only one here who gives a shit about the rules?" His converted Jewish faith constitutes yet another "frame of reference," offering protection from a world in complete disarray while isolating him from the present: "Three thousand years of beautiful tradition, from Moses to Sandy Koufax - you're goddamn right I live in the past!" This longing for absolutes also lies behind his grotesque statement, "Say what you like about the tenets of National Socialism, Dude, at least it's an ethos."

After spreading Donny's ashes on the cliff above the ocean, Walter and the Dude eventually overcome their ideological differences. The end of culture wars is proclaimed when Walter, after apologizing for relating everything to his Vietnam experience, simply suggests, "Let's go bowling." This scene stages the reconciliation between the left and the right, between the student activist who claims to have cowritten the Port Huron Statement and the patriotic Vietnam veteran. With Walter and the Dude in a long and awkward embrace, the Coens transcend postmodern irony and establish companionship as the core value in a society that has become increasingly fragmented and individualistic.

\section{THE BARBER'S DILEMMA}

Ed Crane, the laconic protagonist of The Man Who Wasn't There, has never been able to develop a personal language that would allow him to express his feelings and thoughts. As he states at the beginning of the movie, "Me, I don't talk much. I just cut the hair." Unable to engage in any meaningful communication with the people around him, Ed remains a detached observer of the outside world. The taciturn barber is a man who isn't there - a man whose self is as elusive as the cigarette smoke that acquires visual significance throughout the movie. Although he has been working his daily routine in the barbershop for many years, Ed "never considered [himself] a barber." Lacking the 
ambition to become an "achiever" in life, he "stumbled into it - well, married into it more precisely." Ed seems to have settled into a role, ${ }^{33}$ and his indifference extends to his house in the suburbs, which in 1949 in Santa Rosa, California would have qualified as the epitome of middle-class success in postwar America: "The place was okay, I guess. It had an electric icebox, a gas hearth. It had a garbage grinder built into the sink. You might say I had it made." Even at home, Ed remains a stranger, ignoring his responsibility for entertaining guests at the dinner table. Standing on the porch, he imitates the Hollywood image of the lonely cowboy, smoking and gazing longingly at the lights of his neighbor's house.

The representation of America in The Man Who Wasn't There, a film indebted to James M. Cain's hard-boiled fiction of the I930s and 1940s, ${ }^{34}$ is a prime example of the Coens' postmodern fascination with the hyperreal. What their cinematic style evokes is not a mimetic image of postwar America, but a colorful remix of already mediated representations. Thus reality is transformed into a playful interaction between perception, memory, and imagination. In this vein, the mise en scene of The Man Who Wasn't There bears a striking resemblance to scenes from Edward Hopper's paintings of twentieth-century small-town America, not only in terms of the movie's setting and decor, but also in relation to the atmosphere of solitude that surrounds the characters. The estrangement and utter loneliness that Hopper's figures convey can be felt whenever the camera frames Ed within his professional or family environment. Panning over the facade of Ed Crane's barbershop and framing his house in a typical tree-lined residential area, the camera creates a feeling of absence and isolation. By locating their story in the collective visual history of the Depression era, the Coens present a shattering critique of the postwar myth of the American Dream realized in suburban space.

As Devin McKinney asserts in relation to Fargo, the Coen characters "commit the grave error of living out not the lives they have been given but the lives they envision in their own master narratives." "53 This is also true for Ed Crane, who seeks to transcend his suffocating suburban existence.

${ }^{33}$ For a vivid description of Ed Crane's alienation see Clark Buckner, Apropos of Nothing: Deconstruction, Psychoanalysis, and the Coen Brothers (Albany: SUNY Press, 2014), 33-35.

${ }^{34}$ For a comprehensive reading of The Man Who Wasn't There as an imaginative remake of James M. Cain's two most famous novels, The Postman Always Rings Twice (1934) and Double Indemnity (1936/1943), see R. Barton Palmer, "Thinking beyond the Failed Community: Blood Simple and The Man Who Wasn't There," in Conard, The Philosophy of the Coen Brothers, 267-86. Palmer argues that both Blood Simple and The Man Who Wasn't There rework central elements from Cain's novels 'in order, somewhat paradoxically, to give vigorous voice to one of the novelist's key themes: the failure of community that engenders a desperate yearning for connection to others" (268).

35 McKinney, "Fargo," 32. 
Feeling "locked up in the barbershop, nose against the exit, afraid to try turning the knob," Ed interprets a coincidental encounter with the shady businessman Creighton Tolliver as a sign for him to finally fulfill his yearning for freedom. Tolliver, pretending to look for a "silent partner" for the opening of a dry-cleaning business, is a typical postmodern trickster figure who seduces the mundane character into a world of danger and excess, vitality and opportunity. Ed's business deal with this trickster is merely "a small, ineffectual attempt to overcome his own passivity," "63 but it sets in motion a downward spiral resulting in his death on the electric chair.

The Coens' camera constantly subjectivizes Ed, framing him in the center and then slowly moving forward into a close-up of his face or peering over his shoulder. The audience sees the action unfolding from his point of view. This control over subjectivity that the cinematic apparatus will display throughout the movie is already established by the first scene. As we hear Ed telling us about the barbershop, the camera pulls back from the shopkeeper's bell, then tracks along shelves and briefly settles on his laughing and chatting brother-in-law Frank. Finally, the camera moves into an extreme close-up of Ed's face. His tortured expression while smoking his cigarette sets the tone for the events to follow. In the classical Hollywood narrative, having the viewer identify with the main character is essential for the plot to progress. In the case of The Man Who Wasn't There, however, even though the story is narrated exclusively from the protagonist's point of view, his attitude of utter indifference as well as his striking powerlessness upset the process of audience identification. Thus the film destabilizes the narrative of classical Hollywood, a narrative that presents "psychologically defined individuals who struggle to solve a clear-cut problem or to attain specific goals." ${ }^{37}$

Narration from this subjective point of view not only inscribes the barber's perspective as a filter for events but also emphasizes his limited vision. Moreover, deep-focus photography often undercuts his central position in the frame and thus suggests his impotence in the face of irrational developments. Once inaugurated into the postmodern underworld, Ed can no longer control the course of events. When Tolliver disappears and his money is lost, Ed's life is turned into turmoil by a chain reaction of fateful events: he kills Big Dave in self-defense, but it is his wife Doris who is convicted for the killing and then commits suicide in jail. Even when he attempts to help, he is sure to make the situation worse, pushing everyone around him even deeper into the abyss. The voice-over informs the audience that his wife hanged herself after he "brought her a dress to wear to court and she'd used the belt."

${ }^{36}$ A. O. Scott, "First Passive and Invisible, Then Ruinous and Glowing," New York Times, 3 I Oct. $200 \mathrm{I}$.

37 Bordwell, "Classical Hollywood Cinema," i 8. 
The dream of self-determination is a persistent topic in the Coens' cinema. ${ }^{38}$ However, as Ed Crane is bound to discover, personal freedom is quite impossible to maintain in a universe governed by contingency. Unable to impose order upon an increasingly chaotic environment, he is no longer able to determine his fate. Ed Crane is a wanderer between two irreconcilable worlds, the familiar world of his barbershop and a bizarre world of crime in which everything seems to be collapsing into disarray. Since his psychological motivation remains obscure, most of his actions appear to be performed in an instinctive, almost random, manner. Lacking a stable self that could provide him with a reliable framework for his actions, he loses his bearings within a system of arbitrary, overdetermined signs. After Doris's death, Ed's identity completely disintegrates: "When I walked home, it seemed like everyone avoided looking at me ... as if I'd caught some disease. This thing with Doris, nobody wanted to talk about it; it was like I was a ghost walking down the street." Coming home at night, he feels the heavy burden of emptiness settling on him: "I sat in the house, but there was nobody there. I was a ghost; I didn't see anyone; no one saw me." Reduced to a blank space, a tabula rasa, Ed returns to the familiar world of his barbershop. His profession now provides the only remaining certitude: "I was the barber." Whereas the world outside is subject to constant change, the little "dump" offers a refuge of stability since "sooner or later everyone needs a haircut." What Ed's lawyer Freddy Riedenschneider calls the "barber's dilemma" is the experience of a drastic loss of agency that results in a fundamental crisis of identity. The marginal character of the barber has become central; as "an ordinary man, guilty of living in a world that had no place for [him]," Ed epitomizes the alienation of "modern man," as Riedenschneider puts it in front of the jury.

The film's final sequence, however, calls into question Ed's reliability as a narrator. Only now does the viewer learn that Ed is relating his version of events from inside a prison cell, where he is awaiting his execution. Appropriately for a movie rooted in the realm of postwar popular culture, his life is being transformed into the cover story of a men's magazine. His statement, "They're paying me five cents a word, so you'll pardon me if I've sometimes told you more than you wanted to know," is not just an ironic twist on his reticence. More importantly, it reminds the audience that the story they have been following is tailored to the rules and conventions of the entertainment industry. This becomes obvious when the camera frames Ed sitting at a small table with several tabloids stacked next to his writing pad. Belying the narrative's somber air, the cover headlines - "I Was Abducted by Aliens" and "After Ten Years of Normal Life, I Discover I am an Escaped

${ }^{38}$ See McKinney, "Fargo," 32. 
Lunatic" - suggest that what the audience just watched was merely another lurid tabloid story.

Humans try to make sense of an essentially incoherent, random reality by transforming experience into orderly, logical narratives. Finally, Ed has found a way of using language to create coherence and causality, "to sort it all out." While until now he has been unable to discern a pattern in the swirl of unforeseen events, suddenly "all the disconnected things seem to hook up." Filled with sudden hope, Ed expects that "beyond earth and sky" things will be clearer, "like when a fog blows away." Confronted with the prospect of his death, Ed eventually begins to reflect on the chain reaction of absurd events from a more abstract level, thus transcending his everyman suburban existence by "pulling away from the maze":

While you're in the maze you go through willy-nilly, turning where you think you have to turn, banging into dead ends, one thing after another. But get some distance on it, and all those twists and turns, why, they're the shape of your life. It's hard to explain ...

The Man Who Wasn't There engages in a discussion of the nature of interpretation by simultaneously establishing and parodying the radical skepticism that is so characteristic of the postmodern world-view. When commissioned with the defense of Ed's wife, the star lawyer Freddy Riedenschneider develops a courtroom tactic that is informed by the postulate that there exists no absolute knowledge in the Hegelian sense. Scrutinizing the ever-changing facts of the story, Riedenschneider contends, will not help to discover the truth, but only produce further doubt and thus obscure the boundary between guilt and innocence. According to this headstrong logic, the jury will never arrive at any unequivocal interpretation of the events since it is impossible to tell the story as it "really happened." Riedenschneider's theory harks back to the findings of German physicist Werner Heisenberg, whose account of the uncertainty principle revolutionized modern science. Setting out in 1927 to measure both the position and the movement of energy quanta, Heisenberg discovered that the two measurements were incommensurable. ${ }^{39}$ Riedenschneider rephrases Heisenberg's conclusions:

You wanna test something, you know, scientifically - how the planets go round the sun, what sunspots are made of, why the water comes out of the tap-well, you gotta look at it. But, sometimes, you look at it, your looking changes it. You can't know the reality of what happened, or what would've happened if you hadn't-a

39 See Werner Heisenberg, "The Physical Content of Quantum Kinematics and Mechanics" (1927), trans. John Archibald Wheeler and Wojciech Hubert Zurek, in John Archibald Wheeler and Wojciech Hubert Zurek, eds., Quantum Theory and Measurement (Princeton, NJ: Princeton University Press, 1983), 62-84. 
stuck in your goddamn schnozz. So there is no "what happened." ... Looking at something changes it. They call it the "Uncertainty Principle." Sure, it sounds screwy, but even Einstein says the guy's on to something.

This principle of not-knowing - "Science. Perception. Reality. Doubt," as summed up by Riedenschneider - can be seen as the underlying logic of the Coens' cinema: "I'm saying that sometimes the more you look, the less you really know." Watching their movies, one is constantly challenged by the ambiguous nature of the narratives and visual signs they employ. The camera frames Riedenschneider from high above as he delivers his monologue. Starkly illuminated, Riedenschneider stands in a circle of light. While in the language of Old Hollywood this perspective would suggest wisdom and enlightenment, here the shot has precisely the opposite function, as it parodies the lawyer's pretentious triviality. Thus the movie deconstructs its own narrative principle of "reasonable doubt." With The Man Who Wasn't There, the Coens take the postmodern position continuously evoked by their movies to its absurd extreme.

\section{AUTHOR BIOGRAPHY}

Thorsten Carstensen is Assistant Professor of German at Indiana University-Purdue University Indianapolis, where he teaches courses on German literature and film. His publications include a monograph on Peter Handke and articles on Hermann Broch, Thomas Bernhard, Paul Auster, J. M. Coetzee, and the cinema of Wes Anderson. 